\title{
Wrongful life: some of the problems
}

\author{
Athena N C Liu Glasgow University
}

\section{Author's abstract}

The author considers that some of the reasonings used by both the American and English courts against recognising a wrongful life claim are far from persuasive. However, there may indeed be strong public policy reasons against judicial recognition of such a claim. If judicial remedy is not possible for children in wrongful life situations, society ought to assist them in the alleviation of some of the practical problems caused by deformities.

\section{Introduction}

A wrongful life action is one brought by or on behalf of a child (usually deformed) (1) against the defendant, claiming that because of the negligence of the defendant he or she has to endure a deformed and unhappy existence. The child in a wrongful life claim does not allege that the defendant's negligence caused his or her deformity. Rather, the child alleges that the defendant's negligence, in failing adequately to inform the parents of the risk of a deformed birth, caused his or her birth. That is, had there been no negligence, the child would not have been born to experience the pain and suffering attributable to the deformity. In other words, he or she would have been better off not being born.

Usually, a wrongful life action is brought in conjunction with a wrongful birth claim. This latter claim consists of parents alleging that, had the defendant not been negligent, they would either have avoided conception or terminated the pregnancy. Here the parents are claiming damages to compensate them for the added financial and emotional costs of having and rearing a child (2).

The relative novelty of all these birth-related claims reflects the fact that a new set of responsibilities is being placed on the medical profession as prenatal care becomes more advanced. This advancement in prenatal care means that it is possible for parents to choose whether to have a child on the basis of certain information. Where, as a result of the negligence of a defendant doctor or genetic counsellor, parents are

\section{Key words}

Wrongful life; deformed births. denied the opportunity to make an informed choice as to whether to have a child, or to prevent the birth of a child, our sense of justice would demand that some kind of compensation be given to the injured parties as a recognition that a wrong had been done. Such compensation would, as in all actions of this sort, be designed to restore the plaintiffs, as far as possible, to the situation they would have been in had there been no negligence. Indeed, courts have accepted parents' claims (2).

Wrongful life claims, however, have consistently been rejected by the American courts (3), although recently, there have been signs of change in the American judicial approach towards wrongful life (4). In Britain, however, one can deduce from the only case on wrongful life that judges are utilising the reasonings expressed in past American cases to exclude this type of claim (5).

The aim of this article is to examine some of the reasonings courts have used to reject wrongful life claims. Although most of them are rather unconvincing, there are, perhaps, justifiable reasons which, though not clearly expressed by the courts, operate against judicial recognition of such a claim.

\section{History of wrongful life cases}

'Wrongful life' claims were first brought in the USA by two illegitimate, healthy children. They are now usually referred to as 'dissatisfied life' rather than wrongful life cases. However, the reasonings in these cases have become the basis for later 'true' wrongful life claims.

In the case of Zepeda $\mathrm{v}$ Zepeda (6), a healthy illegitimate child brought an action against his father, claiming injury by virtue of his illegitimate status. The court rejected the claim, one of its reasonings being fear of a flood of litigation.

In 1966, a New York court followed this decision in Williams v State of New York (7). In this case, a child filed a claim against the State for negligently failing to prevent the sexual assault on her institutionalised mother that resulted in her illegitimate birth. The court rejected the claim holding that '[being] born under one set of circumstances rather than another . . . is not a suable wrong that is 
cognisable in court' (8).

The first true wrongful life claim was considered in Gleitman v Cosgrove (9). The plaintiff child was born with defects in sight, hearing and speech after the defendant doctors negligently assured his mother that he would not be harmed by her having contracted rubella (German Measles) in the first trimester of pregnancy. The court recognised that the doctors' conduct did not cause the child's defects. Indeed, they were caused by something over which the doctors had no control. The complaint of the plaintiff, therefore, was not that he should not have been born without defects but that he should not have been born at all. That is, had the mother been informed of the possibility of bearing a child with these defects, the pregnancy would have been terminated and the plaintiff's deformed existence prevented. This claim was again rejected (10).

\section{McKay v Essex Area Health Authority}

There is only one English case on wrongful life and it is on all fours to Gleitman. In McKay v Essex Area Health Authority (11), the Court of Appeal unanimously held that the duty owed to an unborn child was a duty not to injure it. The child had been injured by the infection but not by the defendants. If the child's action were to succeed, it could only do so on the basis of a right not to be born deformed, which in the case of a child deformed before birth by nature or disease meant a right to be aborted (12). Although the doctor owed a duty to the mother to advise her of the infection and of the advisability or desirability of an abortion, it did not follow that the doctor was under a legal obligation to the fetus to terminate its life or that a fetus had a right to die. Such a claim for 'wrongful life' would be contrary to public policy as a violation of the sanctity of human life. Furthermore, the court said that it would be impossible for it to evaluate damages by comparing the value of nonexistence with existence in a disabled state.

The importance of McKay is restricted by the Congenital Disabilities (Civil Liability) Act 1976 which received the royal assent on 22 July 1976 (13). S1(2) precludes children born after its passing a cause of action in wrongful life (14). This is in accordance with the Law Commission's view that no 'wrongful life' claims should lie (15). Their comment is as follows:

'Such a cause of action, if it existed, would place an almost intolerable burden on medical advisers in their socially and morally exacting role. The danger that doctors would be under subconscious pressures to advise abortions in doubtful cases through fear of an action of damages, is, we think, a real one' (16).

A similar view on wrongful life action was also adopted by the Royal Commission on Civil Liability and Compensation for Personal Injuries (17).

\section{Reasonings of the courts}

The vital element of a wrongful life action is that life itself is an injury and that the defendant's negligence caused the birth and thus the injury. Courts have on the whole rejected wrongful life claims for various reasons.

\section{Can existence be an injury?}

First, it has been said that a wrongful life action must fail because existence, albeit with defects, can never be an injury cognisable at law. Thus it has been said that:

'Life - whether experienced with or without a major physical handicap - is more precious than non-life' (18).

Yet it is too rigid to lay down as a matter of principle and substantive law that life with deformities can never be worse than non-life, and that causing someone to be alive with defects can never be an injury to that person. Thus, it has been said that:

'If a court had to decide whether it were better to enter into life maimed or halt than not to enter it at all, it would, I think, be bound to say it was better in all cases of mental or physical disability, except possibly in those extreme cases . . .' (19).

A case that nearly demonstrated that there might be circumstances in which life may be worse than non-life is $\operatorname{Re} B$ (a Minor) (20). A child was born suffering from Down's Syndrome and an intestinal blockage. An operation was required to relieve the obstruction if she was to live for more than a few days. Since the effect of the operation might be that the child would have the normal life-span of a Down's Syndrome person, the court made an order that the operation should be performed. However, Templeman L J said that:

'There may be cases, I know not, of severe proved damage where the future is so certain and where the life of the child is so bound to be full of pain and suffering that the court might be driven to a different conclusion' (21).

The court's pronouncement that life with defects can never be an injury cognisable at law reflects not only its rigid view on the principle of the sanctity of human life, but also its insensitivity to current debates on quality of life, voluntary euthanasia, non-treatment of severely malformed infants and the terminally-ill, and selective abortion of the congenital deformed (22). Implicit in these debates is the idea that under certain circumstances, life can be worse than non-life. In other words, a comparison seems to be intuitively possible.

In the case of $R e$ Quinlan (23), the New Jersey Supreme Court held that a patient could decline medical treatment under certain circumstances even 
if that would mean termination of life (24). In Superintendent of Belchertown State School v Saikewicz (25), a severely retarded adult was afflicted with leukaemia. Evidence indicated that chemotherapy would produce only a temporary remission; moreover, the treatment would produce adverse side-effects. The Massachusetts Supreme Judicial Court affirmed the decision that it would not be in the patient's interests to prolong his life.

Although the above two cases involve judgements that existence is not always better than death, such judgements are essentially identical in nature to that where one expresses the view that one would have been better off not having been born. Death or nonexistence is non-life. Cases of termination of life, therefore, demonstrate that there is no immutable rule to the effect that life is always to be preferred over non-life. Hence one can conclude that under certain (limited) circumstances (26), non-life can be better than life and existence can be an injury.

\section{Can damages be assessed?}

In addition to the claim by the courts that life is always better than non-life, and therefore, life with defects can never be an injury cognisable in law, the courts have also maintained that it will be impossible to measure damages because it will mean comparing between existence with deformities, on the one hand, and 'the utter void of non-existence' (27), on the other hand. Since man knows nothing about the latter, no comparison is possible. Thus, Griffiths $\mathrm{L} J$ said:

'. . . the plaintiff says: "But for your negligence I would never have been born". The court then has to compare the state of the plaintiff with non-existence, of which the court can know nothing; this I regard as an impossible task' (28).

However, the question surely is, can an intuitive comparison be made between life with deformity and non-existence. In fact, both American and English judges have said on a number of occasions that life, even with severe deformities, is better than non-life (9). Implicitly, a comparison is possible and is necessarily being made.

Courts have also said that (assuming comparison between life with deformities and non-life is possible), damages in wrongful life cases are too speculative and therefore they cannot undertake the task of evaluation (28). However, speculative non-pecuniary indicators of damages, such as pain and suffering, loss of consortium and loss of expectation of life (29), have never deterred courts from assessing the amount of damages. Griffiths L J defended the possibility of calculation in relation to these indicators of damages, saying that:

'But the whole exercise, difficult as it is, is anchored in the first place to the condition of the plaintiff before the injury which the court can comprehend and evaluate' (28).

However, just as we know nothing about death in the sense that it is beyond empirical realms (except in religious or metaphysical terms), we know nothing about non-existence. That is, if courts can assess damages for shortened life (30), can they not equally evaluate, in a particular case, whether and to what extent existence is better or worse than non-existence?

Furthermore, it is generally accepted that difficulties of assessing damages cannot be a sufficient reason to defeat an otherwise meritorious claim. Thus in Berman $\mathrm{v}$ Allan (31), the court rejected the impossibility of assessing damages as a sufficient reason against the plaintiff's claim. Where there is no readily available comparison for assessing damages, judicial guesswork is often considered acceptable (32).

\section{Opening of the floodgate}

It has been said (6) that the court's acceptance of wrongful life claims will open the floodgate of litigation. This fear of the flood is not a convincing reason for denying the plaintiff's claim for a remedy. If the plaintiff has a meritorious claim, the fact that a flood of other people in similar positions as the plaintiff will also have meritorious claims should not affect the plaintiff's claim. It merely demonstrates that there is a significant problem to be addressed. If other potential claims are frivolous, then the problem of opening the floodgate does not exist.

\section{Public policy against recognition of wrongful life}

On a number of occasions, it has been said (33) that it is against public policy (upholding the principle of sanctity of human life) for the court to recognise that non-life can be better than life.

Public policy affirming the value of life is not absolute (34). There are, indeed, accepted practices to prevent certain lives from coming into existence. The popular use of various contraceptive devices, legal abortions and sterilisations demonstrates that not all potential lives are considered desirable (35). However, recognition of a wrongful life claim, once a child is born, is slightly different from accepting the desirability of avoiding certain lives coming into existence. Indeed, there may be valid reasons why the English and American courts, in general (36), are unwilling to recognise that non-life can be better than life.

On the one hand, recognition of wrongful life would be consistent with interests of future children. It accepts that where medical knowledge and technology permit, a child should not be born to suffer extreme pain and suffering that could have been avoided but for someone's negligence. Thus, some American judges have talked about a 'fundamental right of a child to be born as a whole functional human being' 
in wrongful life cases (37).

On the other hand, what will be the logical consequences of accepting wrongful life claims (38)? First, it may cast the burden to abort defective fetuses on pregnant women (39). This is possible if the medical profession always give a warning to a pregnant woman that the child may be born deformed. However, it must be said that this manoeuvre by the medical profession will hardly be considered acceptable.

Second, it has been suggested that if a defendant doctor is found to be negligent in treating a particular patient, other doctors would practise defensive medicine (40). If this means that doctors practising medicine in the same negligent manner as the defendant doctor will change their practice in light of the court's judgement, this will only be in patients' interests (41). A negligent finding, however, should have no effect on those whose standard of practice is being upheld by the court. Accepting wrongful life claims may, however, affect attitudes of doctors who may be more inclined to advise an abortion in cases where a child may be born deformed (42). That may be one of the public policy reasons against recognising wrongful life.

Third, would accepting wrongful life claims mean that a doctor or a mother (43) would have a duty to abort defective fetuses even if they were opposed to abortion? Compulsory abortion would be incompatible with a woman's reproductive freedom (44). From the doctors' point of view, this will be inconsistent with the conscious objection clause in the Abortion Act (45). Further, a duty to abort may be unacceptable as it resembles too much the idea of negative eugenics, that is, certain defective lives should be eliminated (46).

Fourth, is the court the proper forum to redress the plaintiff in a wrongful life claim? Is it proper for a court to adjudicate that the plaintiff's life is worse than non-life and thus compensation ought to be awarded? In addition, if life is so unbearable that non-existence would be a better alternative, as the plaintiff alleges, is suicide the solution?

Fundamentally, questions raised by wrongful life actions transcend the legal and philosophical discussions as to whether life can be an injury, and if so, whether assessment of damages is possible, and what are the consequences of judicial acceptance of such claims. In reality, what is more important is that there are children suffering from defective and/or painful existences, and damages are sought in order to make their existences more comfortable and bearable. Compensation, therefore, is the essence of the claim. The fact that a wrongful life claim is seen to be the only available avenue to achieve such an end reflects the inadequacies of social arrangements regarding problems such children face.

Resort on behalf of such children to the law and claims of negligence may also suggest that we would like to see competent medical practitioners (just as with any other profession) be held accountable for their actions. Here, the choice appears to be either that we accept wrongful life and its logical dangers or we may have to abandon medical accountability in this particular situation.

Yet, there is a third alternative: the need of a child in a wrongful life situation for compensation could be met by way of a social security system (47). This would mean that where deformed existence were due to someone's negligence, the child would receive financial help without having to show that life was an injury. Since we would not like to see the erosion of medical accountability, doctors who are responsible for wrongful life births could be disciplined by, perhaps, a medical organisation or other independent authority.

\section{Conclusion}

Although the majority of the reasons given by the courts against wrongful life actions are not necessarily persuasive, one can perhaps say that there are indeed legitimate reasons against their recognition. The American experience may be an indication that society must find an alternative solution to the problems raised in wrongful life claims.

\section{Acknowledgement}

My thanks to Mrs Sheila McLean and Professor Robin Downie who commented on the early draft of this article.

Athena NC Liu, who has a BA in Law is presently writing a doctorate on Reproductive Rights and Artificial Reproduction at the Forensic Medicine and Science Department, Glasgow University.

\section{References and notes}

(1) See 'dissatisfied life' cases, references 6-8, this article.

(2) Sciuriaga v Powell (1980, unreported). CA transcript 597; Emeh v Kensington, Chelsea E Fulham Area Health Authority [1984] 3 All E R 1044; Udale v Bloomsbury Area Health Authority [1983] 2 All E R 522; Thake v Maurice [1986] 1 All E R 497; Sherlock v Stillwater Clinic $260 \mathrm{~N} \mathrm{~W} 2 \mathrm{~d} 169$ (1977). These are sometimes called wrongful pregnancy or conception claims and they usually concern healthy but unplanned births typically caused by negligent abortions or sterilisation procedures. Sometimes cases relate to planned but deformed children. For instance: Berman $\mathrm{v}$ Allan $80 \mathrm{~N}$ J 421, (1979); Park v Chessin 60 A D 2d 80, 400 N Y S 2d 110 (1977); Becker v Schwartz 46 N Y 2d 401, 386 N E 2d 807 (1978); Curlender v Bio Science Laboratories 106 Cal App 3d 811, 165 Cal Rptr 477 (1980); Turpin v Sortini 182 Cal Rptr 337 (1982); Harbeson v ParkeDavis 98 Wn 2d 460, 656 P 2d 483 (1983).

(3) See generally, Foutz T K 'Wrongful life: the right not to be born'. Tulane law review 1979-80; 54: 480; Teff $H$. The action for 'wrongful life' in England and the United States. International and comparative law quarterly 1985, 34: 423.

(4) See VanDerhoef P J. Washington recognises wrongful birth and wrongful life - a critical analysis - Harbeson 
v Parke-Davis, Inc. 98 Wn 2d 460, 656 P 2d 483 (1983), Washington law review 1983; 58: 649.

(5) See McKay v Essex Area Health Authority [1982] 2 ALL E R 771. See also reference (11).

(6) 41 Ill App 2d 240, 190 N E 2d 849 (1963).

(7) $18 \mathrm{~N} \mathrm{Y} \mathrm{2d} 481$ (1966).

(8) See reference (7): 484.

(9) $49 \mathrm{~N} \mathrm{~J} \mathrm{22,} 227$ A 2d 689 (1967).

(10) For a detailed discussion of the case, see reference (3); Foutz.

(11) [1982] 2 ALL E R 771, (C A).

(12) See references $(37-46)$, this article.

(13) See S4(5). The Act does not apply to Scotland.

(14) See also McKay, reference (11): 779.

(15) See Law Commission Report on Injuries to Unborn Children, No 60, Cmnd 5709, paras 46-47 (1974).

(16) See reference (15): para 89.

(17) Report Vol 1; Cmnd 7054-1. para. 1485.

(18) Berman v Allan. 80 N J 421, 425, 404 A 2d 8, 12 (1979). See also Gleitman v Cosgrove, 49 N J 22, 227 A 2d 689 (1967), where it was said that: 'it is basic to the human condition to seek life and to hold on to it however heavily burdened. If Jeffery [the plaintiff] could have been asked as to whether his life should be snuffed out before his full term of gestation could run its course, our felt intuition of human nature tells us he would almost surely choose life with defects against no life at all'. 30, 227 A 2d 689, 693.

(19) McKay v Essex Area Health Authority [1982] 2 ALL E R 771, 782, per Stephenson L J. The judge gave the example of Croke v Wiseman [1981] 3 All E R 862, see reference (26). See also $\operatorname{Re} B$ (a Minor) [1981] $1 \mathrm{~W} \mathrm{~L}$ R 1421.

(20) [1981] 1 W L R 1421.

(21) See reference (20): 1424.

(22) See Mason J K, McCall Smith R A. Law and medical ethics. London: Butterworths, 1983, chapters 7 and 14. See also Mclean S A M. Medicine, morals and the law. Aldershot: Gower Publishing Co Ltd, 1985: chapters $1-5$.

(23) $70 \mathrm{~N} \mathrm{~J} \mathrm{10,335} \mathrm{A} \mathrm{2d} 647$ (1976).

(24) 'We have no doubt ... that if Karen were herself miraculously lucid for an interval ... she could effectively decide upon discontinuance of the lifesupport apparatus, even if it meant the prospect of natural death'. See reference (23).

(25) 77 Mass Adv Sh 2372, 370 N E 2d 417 (1977).

(26) For example, where a child, if born, would suffer irreparable brain damage, be blind, unable to speak and paralysed in all four limbs. This is the example given by Stephenson L J in McKay; see reference (19). Other examples may involve severe cases of spina bifida and Down's Syndrome.

(27) Gleitman v Cosgrove, $49 \mathrm{~N} \mathrm{~J} 22$, at 29, $227 \mathrm{~A} 2 \mathrm{~d} 689$, at 692 (1967).

(28) McKay, see reference (11): 790 .

(29) Loss of expectation of life as an indicator of damages is now abolished by the Administration of Justice Act $1982 \mathrm{Sl}(1)(a)$. The court, however, shall take this aspect into account when assessing damages for pain and suffering.

(30) Rose v Ford [1937] 3 ALL E R 359; Benham v Gambling [1941] 1 ALL E R 7.

(31) $80 \mathrm{~N} \mathrm{~J} \mathrm{421,} 404$ A 2d 8 (1979).

(32) Hawkins v New Mendip Engineering Ltd [1966] $1 \mathrm{~W}$ L R 1341, 1348 per Scarman J, Fones v Griffith [1969] 1 W L R 795, 802 per Harman L J.
(33) See, for example McKay, reference (11): 781.

(34) Mclean, S A M. Medicine, morals and the law. Aldershot: Gower Publishing Co Ltd, 1985: chapter 1.

(35) See the Abortion Act 1967, S 1(1)(b), where one of the grounds for a legal abortion is if the child born will be substantially handicapped.

(36) See VanDerhoef, reference (4) on recent American cases.

(37) See Park v Chessin, 60 AD 2d 80, 88, 400 N Y S 2d 110, 114 (1977), overturned by Becker v Schwartz, 46 N Y 2d 401, 386 N E 2d 807 (1978). See Feinberg, J. Is there a right to be born. In: Rights, justice and the bounds of liberty. Guildford, Surrey: Princeton University Press, 1980: 207; Campbell T, McKay A. Antenatal injury and the rights of the foetus. Philosophical quarterly 1978; 28: 17.

(38) See generally Kass L R. Implications of prenatal diagnosis for the human right to life. In: Humber J $M$, Almeder R F, eds. Biomedical ethics and the law. London: Plenum Press, 1976. For an alternative view, see Morison R S. Implications of prenatal diagnosis for the quality of, and right to, human life: society as a standard, in the same book.

(39) Cf Emeh v Kensington, Chelsea \& Fulham Area Health Authority, reference (2), where it was held that the plaintiff's refusal to abort a child conceived as a result of the defendants' negligence in performing a sterilisation operation was not so unreasonable as to eclipse the defendants' wrongdoing.

(40) See Whitehouse v Fordan [1980] 1 All E R 650 at 658, per Lord Denning MR. '[In America], the damages are colossal . . . Experienced practitioners are know to have refused to treat patients for fear of being accused of negligence. Young men are even deterred from entering the profession because of the risks involved . . . F For the American experience, see: Wood C, ed. The influence of litigation on medical practice. London: Academic Press, 1977.

(41) For the possible difficulties of legal intervention into medical practice, see: Mason J K, McCall Smith R A. Law and medical ethics. London: Butterworths, 1983: 17-18.

(42) See the Law Commission Report on Injuries to Unborn Children, reference (15).

(43) In Curlender v Bio Science Laboratories, it was said that: if a case arose where despite due care taken by the medical profession in transmitting the necessary warnings, the parents made a conscious choice to proceed with a pregnancy, with full knowledge that a seriously impaired infant would be born, that conscious choice would provide an intervening act of proximate cause to preclude liability insofar as defendants other than the parents are concerned. Under such circumstances, we see no sound public policy which should protect those parents from being answerable for the pain, suffering and misery which they have wrought upon their offspring'. $106 \mathrm{Cal}$ App 3d 811, 830-1; 165 Cal Rptr 477,488 (1980).

(44) See Mclean S A M. Right to reproduce. In: Campbell $\mathrm{T}$, Goldberg D, Mclean S, Mullen T, eds. Human rights: from rhetoric to reality. Oxford: Basil Blackwell, 1986.

(45) S4 Abortion Act 1967.

(46) Cf the Abortion Act, 1967, see reference (35).

(47) See Kennedy I, Edwards R G. A critique of the Law Commission report on injuries to unborn children and the proposed Congenital Disabilities (Civil Liability) Bill. Fournal of medical ethics 1975; 3: 116-121. 